\title{
Endemic Hydro climatic Flood Hazards in Some Cameroonian Coastal Cities: The Hand of Man or the Work of Nature?
}

\author{
Balgah Sounders Nguh* and Nkemasong Nicasius Anumveh \\ Department of Geography, University of Buea, Cameroon \\ *Corresponding author: Balgah Sounders Nguh, Department of Geography, University of Buea, Cameroon

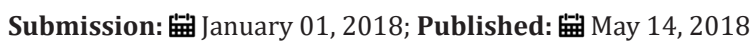

\begin{abstract}
Rapid urbanisation of the three Cameroon's coastal cities of Douala, Kumba and Limbe has provoked and sustained intense competition for the limited space by burgeoning urbanites and broadening scope of lucrative economic activities within the cities. The unfortunate aspect has been that the urban poor are being bided off from suitable land spaces and coerced to source a living on fragile urban zones as river valleys, poorly reclaimed marshes on urban flood plains, which are high risk zones for flooding. Empirical and statistical analyses complemented by field investigations, and mapping techniques have been used to establish and exposed some hitherto latent dimensions of this perennial demise of these urban centres.

Contrary to earlier explanations that saw man as the principal architect of his own doom, present findings reveal but the imposing role of hydroclimatic excesses reinforced by the urban geomorpoholigcal dispositions of these urban landscapes as the primal triggers of this seasonal urban crisis. This makes the hazard of seasonal urban flooding in these cities more of the work of nature than the hand of man. Based on this, it is recommended that current flood management strategies should be restructured to top target the root causes rather than cosmetically targeting the consequences, if these cities must integrate the main path to urban sustainability come 2030 as targeted set in the Sustainable Development Goals (SDGs).
\end{abstract}

Keywords: Flood; Urban flooding; Seasonal flooding; Coastal city; Flood risk; Vulnerability; Sustainability

\section{Introduction}

Despite predictions at the start of the $20^{\text {th }}$ century heralding a slowing down and even reversal of global urbanisation trends with marked mass exodus from the city [1], rapid urbanisation remains a visible phenomenon of our time, particularly in the Less Economically Developed Countries (LEDCs) which Cameroon is part. Cameroon in particular has defied this urban revolution prophesy since between 1960 and 2010, the proportion of urbanites in Cameroon rose from 48.8\% to 52\% (Africa Atlases: Cameroon, 2010:120). Some of the fastest growing urban centres of Cameroon lie within the Coastal Lowlands. Remarkable examples are three cities of Douala, Kumba and Limbe.

Just as in other cities of the LEDCs this concentration of burgeoning human numbers in urban centres has induced constraints on the limited "ecumene". This very instance has initiated and engendered a stiff competition of survival for existence for "lebensraum" between man residential space and space for his lucrative economic activities. This process of urban space colonisation and succession is at the genesis of numerous economic, social and environmental problems that appear to mask the benefits of the process.
Periodically, growing tides of environmental refugees are generated within the modern cities especially those of the Developing Countries induced by many hazards notably geohazards.

Those provoked by hydroclimatic caprices as flooding are more dramatic and have caught much research attention. The bulk of the urbanites in Cameroon as in other Third World countries are relegated to fragile and high risk vulnerable land spaces which they occupy illegally. This act of survival in these disaster prone zones unfortunately puts them at a collision course with many hazards, of which hydroclimatic caprices as floods appear on frontline. Floods therefore are among the most common causes of disasters in cities in Cameroon especially those near the coast. The melancholic story of city flooding in Cameroon in general is quite preoccupying. Between 1998 and 2006 only, 4,200 people were affected by flooding in Cameroon.

In 2007 alone, the number of affected persons rose to more than 10,000. This number increased to 25,000 in 2008 and nearly 52,000 in 2012 (Centre for Research on the Epidemiology of Disasters Emergency Events Data Base; EM-DAT). This reveals that 
urban flooding scenarios stand out increasingly as an ill wind that blows no one in the good of Cameroon. The very persistence of this disaster and its dimension after 2015 remains a signal of the failure of the Millennium Development Goal 7 (Ensure Environmental Sustainability) Target 4 which called for significant improvement in the lives of at least 100 million slum dwellers by 2020 (Urban Sustainability). This disaster remains a global concern as it is implied in the Sustainable Development Goal 11 (Make cities and human settlements inclusive, safe, resilient and sustainable) for 2030 and so merits continuous research.

\section{Statement of the Research Problem and justification of the Research}

Urban flooding that was primarily a concern of municipal and environmental governance has now attained a "disaster status". Consequently, the attention of environmental scientists and disaster managers has been drawn. Cameroonian cities are no exceptions. Investigations into urban flooding scenarios in Cameroon abound but some of the much researched and documented cases are those of Douala and Limbe but also increasingly Kumba have probed into flooding in Limbe while Fogwe and Asue for Kumba in 2016 [2]. Studies in other metropolitan areas of Cameroon have been done by $[3,4]$ in Douala. All exposed the dimension of this meteo-hazard in terms of its manifestation, vulnerability, consequences, and the myriad of anthropic-linked triggers, the combating measures and recommendations.

This plethora of studies may push one to the conclusion that investigations into the story of urban floods in Cameroon have found their rest. This will be unfortunate because despite these studies and recommendations, the seasonal urban flooding scenarios with even heightening magnitudes as shown in (Figures $1 \mathrm{~A}-\mathrm{C}$ ), remain recurrent. The scale of these flooding scenarios lend credence to the fact that at least a research imperative still remains in the domain of urban flood risks in Cameroon. Furthermore, all inner city flood management strategies in Cameroon seemingly have been dwarfed by rising flood tides. Revisiting the urban flood story in Cameroon in a bid to examine more closely the triggers becomes a sine qua non for putting forward a new blue print for containing intra-urban floods. The research puzzle outlined at this juncture is "have the causal factors widely articulated been analysed properly for the identification of the root triggers, and what is the natural susceptibility of the urban landscape to flood incidence?"

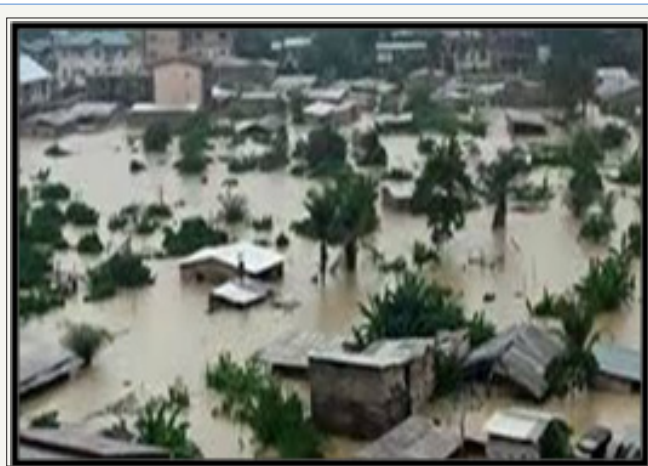

Figure 1A: July 2015 Flood in Douala July Floods.

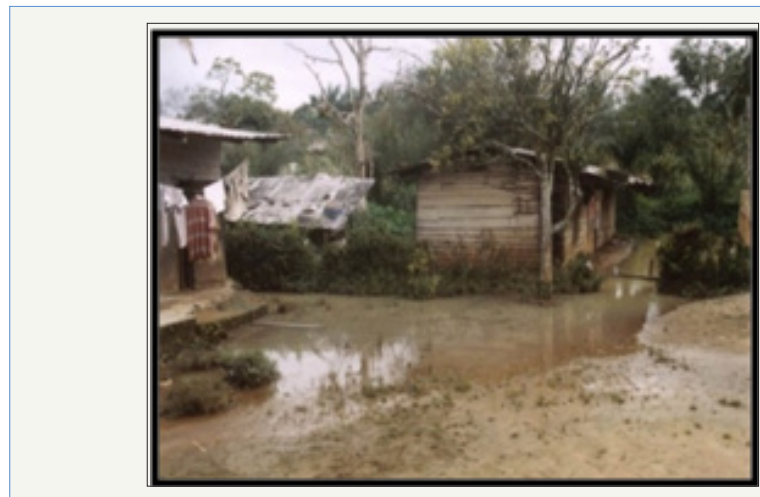

Figure 1B: July Floods in the Fiango-Kosala trough submerge a bridge.

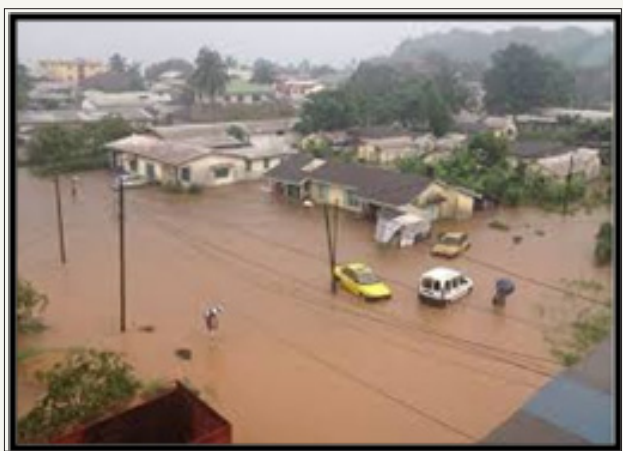

Figure 1C: August 2014 Heavy floods submerge houses in Isokolo Limbe.

The current paper is justified on these population agglomerations within the coastal lowlands of Cameroon currently suffering from recurrent high incidence of floods with a return period of just one year. This is more compelling because the consequences of the flood events are on the rise. Consequently, flooding scenarios in these cities will catch continuous research attention. The current paper is therefore a research step in the right direction of attaining the urban sustainability concern heralded in Target 4 of the $7^{\text {th }}$ UN Millennium Development Goals and Goals 3, 11 and 13 of the post 2015 Millennium Development Goals now called the UN 17 Sustainable Development Goals.

\section{Research objectives and hypotheses}

The cardinal objective of the paper therefore is to revisit the urban flood story in Cameroon in a bid to re-assess the trigger mechanisms to establish the root cause(s). The main tentative hypothesis is that "urban flooding scenarios in Cameroon are more the work of nature than the hand of man".

\section{Definition of key terms}

This paper considers the meanings to the key words used as follows:

a) A flood is the covering by water of land not normally covered by water (European Union Floods Directive).

b) Urban flooding is the inundation of land or property in a built environment, particularly in more densely populated areas caused by rainfall and overwhelming the capacity of drainage systems (storm sewers). 
c) Seasonal flooding therefore refers to flooding that is limited to some parts of the year, mostly the rainy season. This is why the paper talks much of rainy season flooding.

d) Flood Risk is a combination of the probability and the potential consequences of flooding from all sources (rivers and sea, lakes, direct rainfall, rising groundwater and artificial sources as reservoirs and canals) that overwhelms sewers and drainage systems.

\section{Conceptual framework}

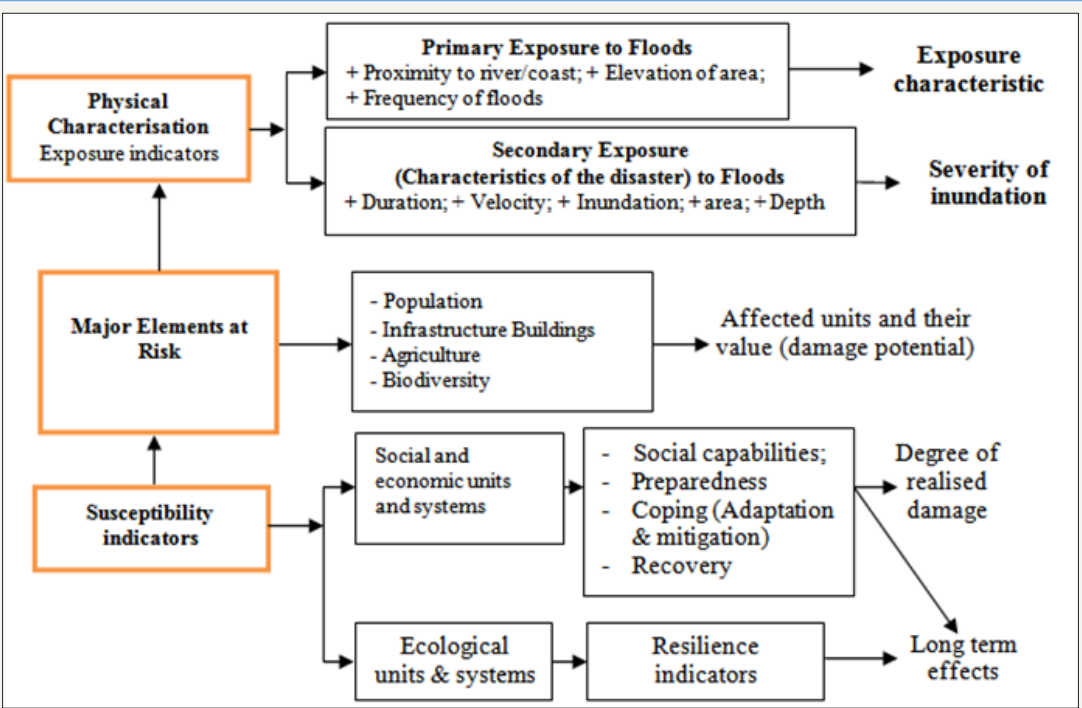

Figure 2: Disaster Vulnerability Analysis Model (Modified for flood analysis relevance).

The Disaster Vulnerability Analysis Model of Frank and GRINP (2005) is considered in this study for vulnerability analysis (Figure 2). This has been applied earlier in some locations within the study area based on the "Mount Cameroon Surveillance" mission of the Ministry of Mines and Technological Development. It has been modified however to have its direct relevance to flood disasters.

\section{The study area}

The indicators considered in the analysis are the characterisation of the physical environment, characterisation of the exposed elements is element-at-risk, hazard assessment and zoning and risk analysis in terms of hazard plus value and vulnerability of the elements at risk.

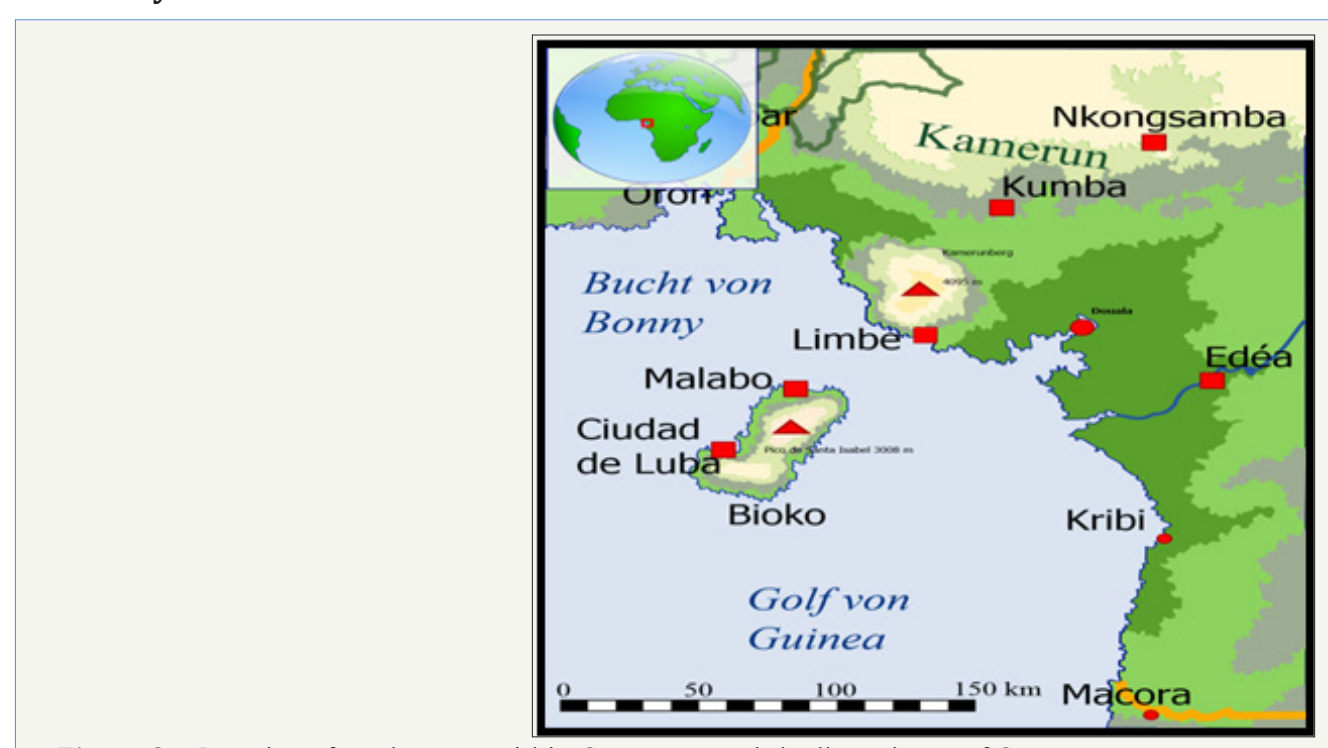

Figure 3a: Location of study areas within Cameroon and the littoral part of Cameroon.

The three urban centres of Kumba, Limbe and Douala under study lie at varied points on the south western part of the Coastal Lowlands of Cameroon as shown on (Figure 3). The geographical coordinates for these are Douala $\left(04^{\circ} 00^{\prime} 16^{\prime \prime} \mathrm{N}\right.$ and $009^{\circ} 43^{\prime} 53^{\prime \prime}$
E), Kumba ( $4^{\circ} 38^{\prime} \mathrm{N}, 9^{\circ} 27^{\prime} \mathrm{E}$ to $\left.4.633^{\circ} \mathrm{N}, 9.450^{\circ} \mathrm{E}\right)$ and Limbe $\left(3^{\circ}\right.$ $45^{`} \mathrm{~N}, 9^{\circ} 10^{`} \mathrm{E}$ to $\left.4^{\circ} 15^{`} \mathrm{~N}, 9^{\circ} 15^{\circ} \mathrm{E}\right)$. Administratively, they are in the Littoral (Douala) and South West (Kumba and Limbe) Regions of the country. Their urban hydro-geomorphology has similarities. 
Their average relief is generally below $250 \mathrm{~m}$ ASL. That of Douala is $30 \mathrm{~m}$ ( $0 \mathrm{~m}$ to $60 \mathrm{~m}$ ), Kumba $230 \mathrm{~m}$ (210m to $250 \mathrm{~m}$ ) and Limbe $185 \mathrm{~m}$ (0m to $370 \mathrm{~m})$.

In terms of straight line distance from the Atlantic Ocean, they are located at less than $100 \mathrm{~km}$ from the shores of the Atlantic Ocean. Douala lies at $24 \mathrm{~km}$ inland, Kumba at $80 \mathrm{~km}$ while Limbe is at the seashore $(0 \mathrm{~km})$. They however lie within different drainage basins as Kumba is within the Mungo basin, Douala in the Nkam-Wouri basin while Limbe is on the shores of the Atlantic Ocean. These cities have undulating landscapes, dissected by many river valleys that have been transformed into residential spaces and urban agricultural zones. The urban change maps (Figure $3 \mathrm{~b}$ ) reveals that the spatial limits of these cities have expanded significantly between 1980 and 2010. Projections from the 2005 Population Census published figures reveal that currently, they jointly house above 2.5 million Cameroonians. Their urban potentials and significance in the urban hierarchy of Cameroon are shown on (Table 1).

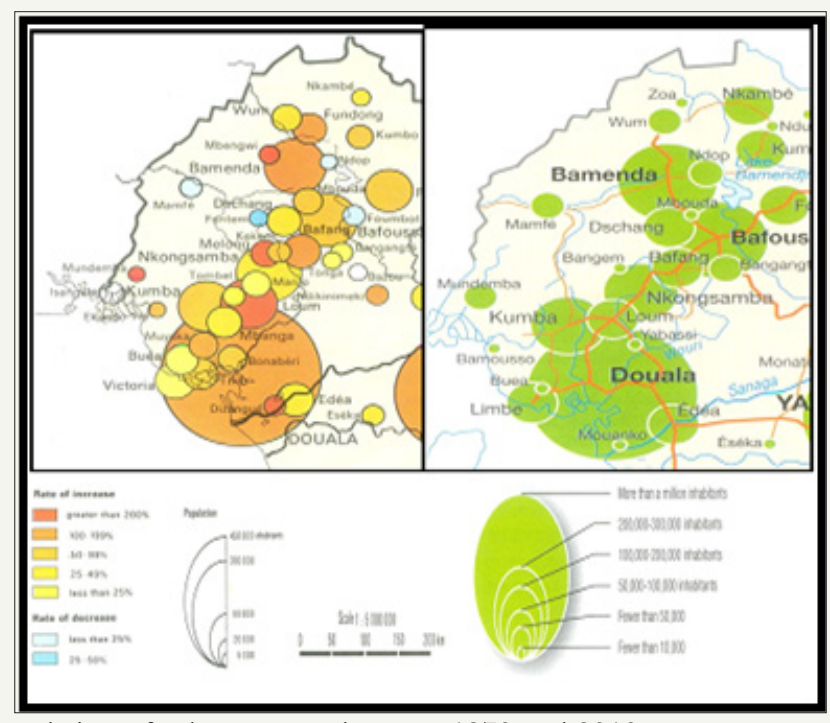

Figure 3b: Evolution in the number and sizes of urban centres between 1970 and 2010.

Table 1: The Urban Hierarchy of the Study Area.

\begin{tabular}{|c|c|c|c|c|}
\hline City & Surface Area $\mathbf{( k m}^{\mathbf{2}} \mathbf{)}$ & Projected Population & Rank in the Region & Rank Nationally \\
\hline Douala & 210 & $2,000,000$ & $1^{\text {st }}$ & $1^{\text {st }}$ \\
\hline Kumba & 800 & 400,000 & $1^{\text {st }}$ & $8^{\text {th }}$ \\
\hline Limbe & 671 & 111.201 & $2^{\text {nd }}$ & $13^{\text {th }}$ \\
\hline
\end{tabular}

Sources: *Surface Areas from various city plan given by their Council Survey Departments.

**Population projected from the 2005 Population Census published figures.

It is deciphered from the table that the cities fall within the top 15 cities on the urban hierarchy of Cameroon. It has been stated that many parts of these cities are built around rivers or on lowelevation sites on the coasts, making them prune to flooding. The terrestrial geography and the concentration of people make these areas vulnerable to flooding and stand to face significant impacts from disasters as floods. This makes them worthy areas as seasonal flood case studies.

\section{Methods and Procedures}

\section{Data generation}

This study made use of the multidimensional investigation procedure. The general research procedure adopted was survey with the compound sampling technique (stratified random sampling method) used.

The two main phases of data sourcing were:

Empirical formulae analysis phase: The rational formula (Lloyd-Davis Method date) was used for runoff forecasting and prediction. This generated data for flood occurrence probability. This analysis was deemed expedient because the landscape of the cities understudy has a hydrology (crisscrossed by rivers and tributary streams) that naturally favours meteorologically induced floods. Incorporated into this analysis was the mean rainfall intensity. This is important since it largely determines the finality of storm events: whether generating surface runoff (overland flow) or infiltration. This analysis took an annual and seasonal character.

Field observation phase: Through this data was gathered to update existing spatial information on the flood incidences. This constituted the basis for the mapping of flood vulnerability zones.

\section{Data processing and presentation phase}

General statistical analysis was done using the Microsoft Excel Package Version 10.0 and the Statistical Package for Social Sciences (SPSS) version 20. These permitted the collation of the information and also thinned down the raw data just to the very relevant. Results are presented as flood vulnerability mappings, tables of specifications, graphs and pictures. 


\section{Results and Discussion}

\section{Flood vulnerability analysis}

A logical starting point in flood disaster analysis studies is runoff prediction and forecast study. In this study, run off forecasting has been considered since it serves warning purposes and assesses the effects of extreme rainfall input on runoff. Furthermore, high flow predictions and analysis is of greater significance, because of its damage potentials. The rational formula (Lloyd-Davis Method), an improvement of the original empirical formula for runoff prediction and forecasting used is expressed as follows:

Qpk $=$ CIA

Table 2: Summary Annual Runoff Rates.

\begin{tabular}{|c|c|c|c|c|c|c|c|}
\hline City & $\begin{array}{l}\text { Mean Annual } \\
\text { Rainfall Totals } \\
\text { (mm) from } \\
1970-2016\end{array}$ & $\begin{array}{l}\text { Number of } \\
\text { Rain days }\end{array}$ & $\begin{array}{l}\text { Coefficient of } \\
\text { Runoff (C) }\end{array}$ & $\begin{array}{c}\text { Mean Rainfall } \\
\text { Intensities(I) in } \\
\mathrm{mm} / \text { day }\end{array}$ & $\begin{array}{c}\text { Surface Area } \\
\text { of Cities(A) in } \\
\mathrm{Km}^{2}\end{array}$ & $\begin{array}{c}\text { Rate of Runoff } \\
\left(Q_{p k}\right) \text { in } \mathrm{m}^{3} / \mathrm{s}\end{array}$ & $\begin{array}{c}\text { Proportion of } \\
\text { Annual Rainfall } \\
(\%)\end{array}$ \\
\hline Douala & 4175.6 & 215 & 0.69 & 19.4 & 210 & $2,811.1$ & 67.3 \\
\hline Kumba & 2230.9 & 155.6 & 0.46 & 14.3 & 800 & $5,262.4$ & 235.9 \\
\hline Limbe & 4968.1 & 165 & 0.53 & 30.1 & 671 & $10,704.5$ & 215.5 \\
\hline
\end{tabular}

Sources: *Nkemasong, 2014 and updated from Google climate data

**Empirical Analysis

Note: Surface areas are taken from City Surveys Departments.

$\mathrm{C}$ values were calculated for different land uses considering that cities have predominantly loamy soil texture and that they are largely urban but with some index of rurality. Thus, some urban and rural land uses were considered.

The predicted runoff high (peak) flow values for the cities are shown on (Table 2). The calculated $Q_{\mathrm{pk}}$ values reveal that these cities would generate more than 2500 cumecs of overland flow annually from rainfall (storm). The surface run off potentials and significance are clearer when the $Q_{\mathrm{pk}}$ is expressed as a proportion (\%) of the annual rainfall totals. Extremely high rates of overland flow generation occur in the city of Kumba followed by Limbe and then Douala. These differences in run off potentials are linked more to the variations in their terrestrial geography and geology, than mere hydro-meteorological tenets.

Kumba and Limbe generate more overland flow because they have steeper slopes and less porous soils. On the other hand, Douala that generates less naturally lies within a sedimentary basin. This gives the landscape characteristics as porous, sandy textured soils and a more gentle topography that reduce the overland flow

Table 3: Summary Peak Rainy Season Runoff Rates.
Where, $Q_{p k}$ is the peak runoff rate (maximum discharge or flood index in $\mathrm{m}^{3} / \mathrm{s}$ ) as a fixed proportion or ratio of rainfall input;

$\mathrm{C}$, the runoff coefficient indicating the percentage of rainfall which appears as surface runoff (the values here have been averaged from empirical values based on American Society of Civil Engineers of 1970 and Dunne and Leopold of 1978);

I, is spatially uniform rainfall (mean intensity established as the quotient between rainfall and number of rain days); and

A, is the area of catchment in $\mathrm{Km}^{2}$, considered here as the surface area of the cities and their immediate regions Ayoade, 1988 and Jones, 1996. This formula remains the most successful and widely used empirical formula for urban drainage requirements.

\begin{tabular}{|c|c|c|c|c|c|c|c|}
\hline City & $\begin{array}{c}\text { Total Rainfall } \\
\mathbf{( m m )}\end{array}$ & $\begin{array}{c}\text { Proportion of } \\
\text { Annual Total } \\
\mathbf{( \% )}\end{array}$ & $\begin{array}{c}\text { No. of Rain } \\
\text { days }\end{array}$ & $\begin{array}{c}\text { Proportion (\%) } \\
\text { of total No of } \\
\text { days (153) }\end{array}$ & $\begin{array}{c}\text { Mean Rainfall } \\
\text { Intensity } \\
\text { (mm/day) }\end{array}$ & $\begin{array}{c}\text { Proportion (\%) } \\
\text { of wet season } \\
\text { rainfall }\end{array}$ \\
\hline Douala & $2,731.9$ & 65.4 & 130 & 85 & 21 & $3,042.9$ & 111.4 \\
\hline Kumba & $1,385.8$ & 62.1 & 113.9 & 74.4 & 12.2 & $4,489.6$ & 324 \\
\hline Limbe & $3,639.3$ & 73.3 & 107.2 & 70.1 & 34 & $12,091.4$ & 332.2 \\
\hline
\end{tabular}

Source: Empirical Analysis.

generation capacity. The flood vulnerability level of these cities are exposed more when their overland flow generation potentials for the five peak-rainy season months (June, July, August, September and October) are analysed. The peak rainy season situation is shown on (Table 3).

It is deciphered from (Table 3) that all three cities have overland flow potential above $100 \%$ for within the peak rainy season months. Going by this index, the city of Limbe becomes the most highly prone to floods, followed by Kumba and then Douala. Vulnerability of these cities to rainy season flooding is reinforced by the highly skewed pattern of intra-annual distribution of rainfall totals and mean daily rainfall intensities, indicating a high degree of seasonality. In all the cities at least $60 \%$ of their annual total rainfall occurs just within these five peak rainy season months, signalling a high rainfall concentration ratio. 
Limbe receives the highest proportion (73.3\%) within the five months, followed by Douala (65.4\%) and then Kumba (62.1\%). These indicate clearly that the likelihood for natural seasonal flooding is high. The probability of natural flood occurrence in the rainy season becomes even higher when the index of the proportion of rainfall days to the total number of days within the peak rainy season months are analysed. With all cities having above $70 \%$ of the days within these five, months receiving rainfall and within intensities generally above $10 \mathrm{~mm}$ /day that floods should occur is just natural. The values of the index are indicative of the fact that there is continuous rainfall almost non-stop for 153 days.

Based on this, the city of Douala stands out with the highest likelihood for natural flood occurrence. This is because up to $85 \%$ (130 days) of the 153 days receive rainfall and with intensity as high as $21 \mathrm{~mm}$ /day. This is followed by Kumba (74.4\%) and then Limbe (70.1\%). Hydrologically, the infiltration capacity of the soils in these cities is exceeded under these conditions of inputs of meteoric water. Overland flow is thus consequent and in great volumes as indicated by values of $Q_{p k}$ flood occurrence is no surprise. This empirical analyse on run off forecasting and rainfall characteristics reveals unequivocally that these three cities on the coastal lowlands of Cameroon have the probability of flood occurrence.

The recurrent flood incidences in the cities of Douala, Kumba and Limbe, with return periods of just a year are the natural order of events since these cities are naturally vulnerable to flooding. Hydroclimatologically, therefore, flooding becomes a natural phenomenon with or without human implantation on the landscape. The hydroclimatic dispositions, reinforced by the terrestrial geography and geology of the cities, set the stage for floods occurrence. That floods should occur within them is thus a natural phenomenon and not a hydroclimatic misnomer. It would rather be a hydroclimatic anomaly therefore if floods do not occur within these cities.

\section{Spatial dimension of vulnerability scenarios}

When all the indices of flood analysis are coupled, the cities can be ranked in terms of degree of vulnerability to flooding. Naturally, the city of Limbe stands out as the most vulnerable to flooding, followed by Kumba, while Douala is the least vulnerable. Any distortion of this order transcends the operation of natural forces. The integration of the primary exposure parameters (proximity to rivers/ coast and the elevation of the terrain) of the disaster vulnerability model into the analysis indicates that there is a likelihood of spatial segregation in flood risks vulnerability within these cities.

It is important to stress that flood risks have both spatial and temporary dimensions. Following the landscape characterisation of these cities, some zones are more vulnerable than others and stand out as seasonal flood endemic zones. Using the Risk-Based Sequential Approach, flooding areas have been classified according to flood risk probability and flood risk vulnerability. Based on indicators as recurrence, duration and area size affected, the flood prone zones have been categorised into three levels of risk and vulnerability as shown on (Table 4).

Table 4: Classification of flood areas by Risk probability and vulnerability.

\begin{tabular}{|c|c|c|c|c|}
\hline $\begin{array}{l}\text { Zone } \\
\text { Code }\end{array}$ & $\begin{array}{l}\text { Level of Vulnerability } \\
\text { (Category) }\end{array}$ & Douala & Kumba & Limbe \\
\hline $1 \mathrm{~A}$ & $\begin{array}{l}\text { Very High Probability (****) } \\
\text { These are functional flood plains where water } \\
\text { has to flow or be stored in times of flood. Land } \\
\text { that has an annual probability of flooding of } 1 \\
\text { in } 20(5 \%) \text { or greater in a year or is designed } \\
\text { to flood in an extreme }(0.1 \%) \text { flood. }\end{array}$ & $\begin{array}{c}\text { Akwa Nord, SIC Cacao, Diedo } \\
\text { and Makepe }\end{array}$ & $\begin{array}{l}\text { Malabo Quarter to } \\
\text { Preventive, Njuki valleys } \\
\text { in the Nurses Quarter and } \\
\text { Kumba Town (Mokube and } \\
\text { Lumumba Streets) down to } \\
\text { Sonac and Lido Streets }\end{array}$ & $\begin{array}{l}\text { Down Beach Church Street, } \\
\text { Mile One }\end{array}$ \\
\hline 1B & $\begin{array}{l}\text { High Probability }(* * *) \\
\text { Have } 1 \text { in } 100 \text { or greater annual probability of } \\
\text { river flooding }(>1 \%) \text { or a } 1 \text { in } 200 \text { or greater } \\
\text { annual probability of flooding from the sea (> } \\
0.5 \%) \text { in a year. }\end{array}$ & $\begin{array}{c}\text { Ndogpassi, Nylon, Missoke, } \\
\text { lowlying areas of Ngangue, } \\
\text { Bonaberi zone notably } \\
\text { Mambanda }\end{array}$ & $\begin{array}{l}\text { Ibo Quarter, Ntoko Street, } \\
\text { Cow fence- Buea Road, } \\
\text { Fiango-Kosala Trough, } \\
\text { Paradise Street }\end{array}$ & $\begin{array}{l}\text { New Town, Clerk's Quarter, } \\
\text { Njengelle Quarter, Gardens }\end{array}$ \\
\hline 2 & $\begin{array}{c}\text { Medium (Moderate) vulnerability }(* *) \\
\text { Have between } 1 \text { in } 100 \text { and } 1 \text { in } 1,000 \\
\text { probability ( } 1 \% \text { to } 0.1 \%) \text { in a year of river } \\
\text { flooding, and/or between } 1 \text { in } 200 \text { and } 1 \text { in } \\
1,000 \text { annual probability sea flooding }(0.5 \% \text { to } \\
0.1 \%) \text { in a year. }\end{array}$ & $\begin{array}{c}\text { Bessengue, Bonamoussadi, } \\
\text { Bepanda }\end{array}$ & $\begin{array}{l}\text { Krama Area, Treasury } \\
\text { Street, Meta Quarter }\end{array}$ & $\begin{array}{l}\text { Lumpsum, Cassava Farm, } \\
\text { Mawoh, Poto-Poto Quarter } \\
\text { and Mabeta New Lay-out. }\end{array}$ \\
\hline 3 & $\begin{array}{l}\text { Low Vulnerability }(*) \\
\text { Have less than } 1 \text { in } 1,000(<0.1 \%) \text { annual } \\
\text { probability of river or sea flooding. }\end{array}$ & $\begin{array}{c}\text { Bonapriso, New Town- } \\
\text { Aeroport, Village Zone, Cité de } \\
\text { Palmiers, Bios des Singes, and } \\
\text { Bonanjo }\end{array}$ & $\begin{array}{c}\text { Hausa Quarter, Alaska } \\
\text { Street }\end{array}$ & $\begin{array}{l}\text { Limbe Camp } \\
\text { Bota, Mile One }\end{array}$ \\
\hline
\end{tabular}

$* * * *$ Almost permanent flooding during the peak rainy season month

$* * *$ Occurrence weekly - lasts for days and flood waters ubiquitous 
** Occurrence monthly - lasts for a maximum of day and flood waters sporadic

*Occurrence only after very heavy storms (ephemeral- lasts for few hours, no permanent flood waters

Note: (1) This classification is based on the Defra/Environment Agency research on Flood Risks to people (FD2321/TR2) in part.

(2) This design of classification considers that there are no existing defence systems to floods.

The figures expose the fact that low lying locations as river valleys and coastal mudflats are the very highly vulnerable zones within the cities during storms. Coastal locations are even extremely vulnerable because their exposure indicators favour rapid floods development. This is the case of the cities of Douala and Limbe that have contacts with the Atlantic Ocean. Limbe spreads out within the Ambas Bay on the Atlantic Coast while Douala (though located at some $24 \mathrm{~km}$ from the Atlantic Ocean), spreads on the wide estuary of River Wouri and therefore has its oceanic contact through tidal swash effects. The severity of inundations in these areas is heightened by the possibility of reinforced flooding due to the effects of potential sea level rise associated with climate variability and change.
As such, areas as Mambanda on the western bank of the River Wouri and parts of Down Beach Limbe have additional flood episodes from tidal surges. These flood events occur irrespective of the season. Inhabitants feel the floods more during the dry season they occur when all other areas are dry. The built-up areas on river valleys, flood plains and coastal mudflats thus are frequently invaded by floodwaters. These areas are extremely vulnerable because the low lying nature of the terrain reduces the speed of outflow of excess storm discharge water from the land relative to the rate of input from rainfall. However, it facilitates the piling up of dirt carried by overland flow that blocks drains and other natural water causeways.

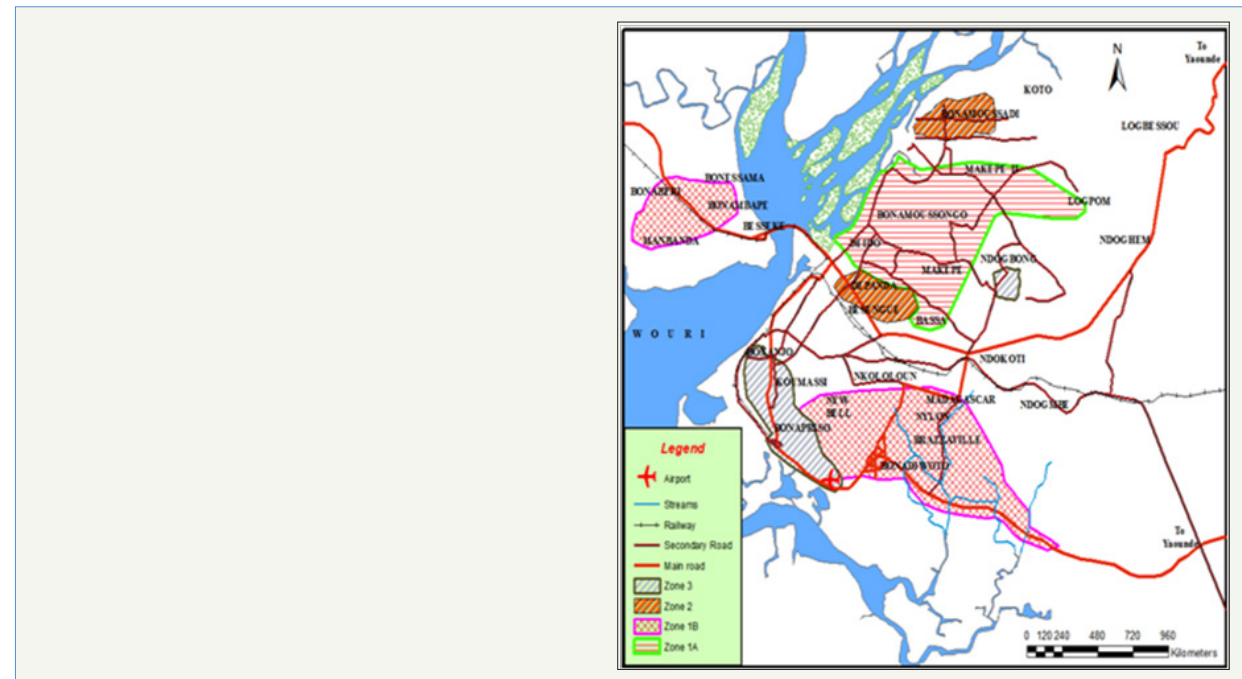

Figure 4: Location of Flood Prone Areas within the cities.

Figure 4a: Flood Prone Zones in Douala.

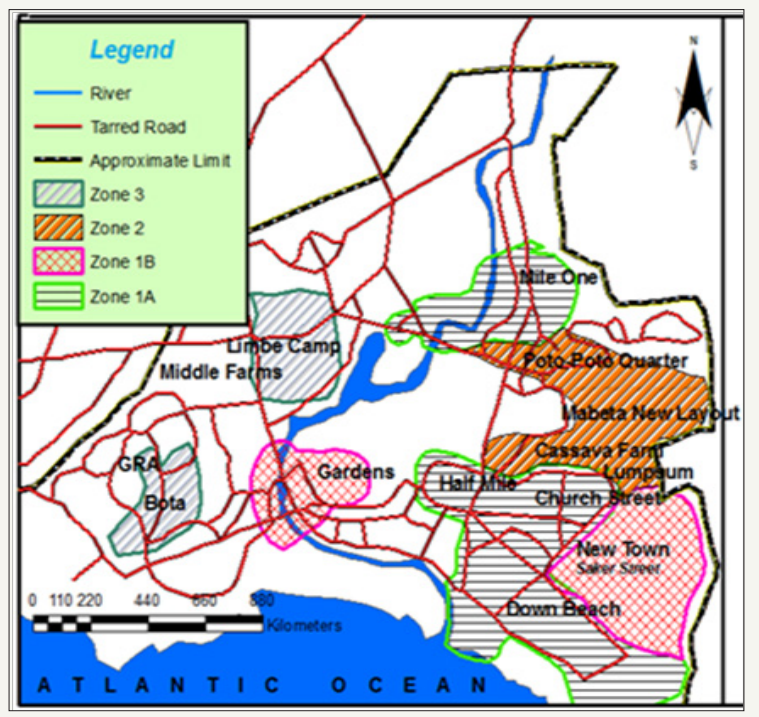

Figure 4b: Flood Prone Zones in Limbe. 


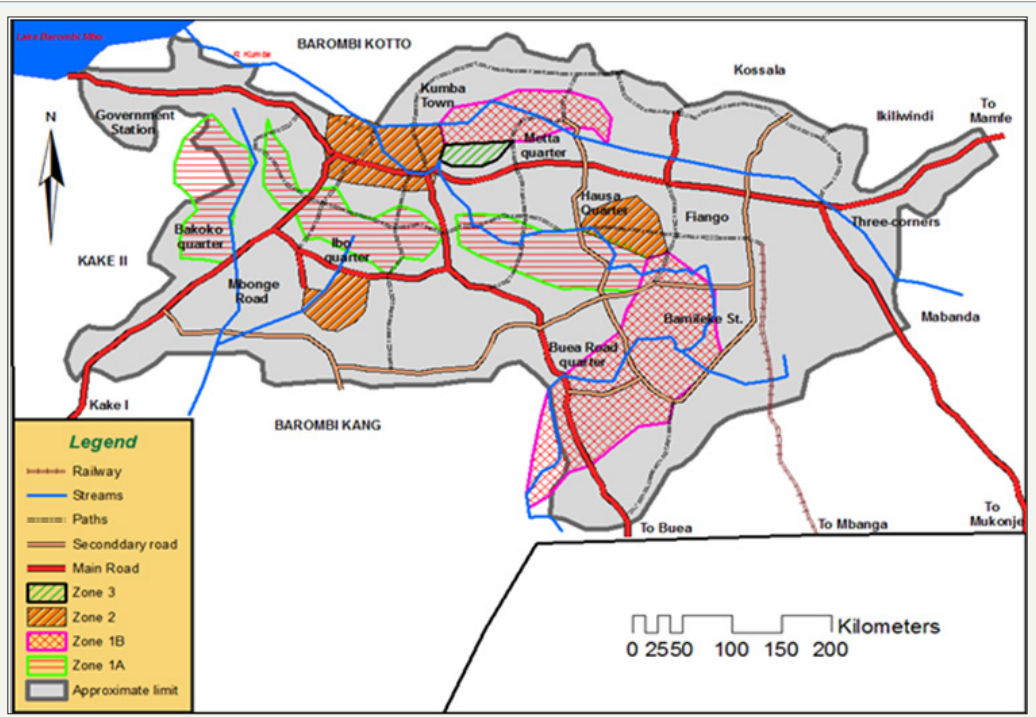

Figure 4c: Flood Prone Zones in Kumba.

The risk factor in these locations is very elevated since they have high concentration of people mainly within the low income bracket. In fact, in all the precarious locations investigated in Douala, Kumba and Limbe, the inhabitants are poor farmers, fishermen, petty businessmen and low income civil servants. The most vulnerable category of the population is the low-income earners, and poor new migrants (poor rural-urban migrants) who occupy settlements in urban flood plains and flood-prone embankments, those living in flimsy houses, those without insurance or financial reserves, the elderly and the infirm (Figure 4).

The high concentration of these low income persons in such high risk flood zones is because the locations are cheaper to obtain. Furthermore they favour the growth of illegal settlements since building regulations are implemented rigorously within them. Furthermore, poverty can drive people to settle and work in precarious locations such as unstable river banks in farming areas. These sites are historically avoided by the better-off but often settled by the poorest in the community because of the availability and/or proximity to sources of economic livelihood.

This revelation ties with earlier conclusions that the neighbourhoods most vulnerable to flooding tend to be those with low household income, poor housing quality and low levels of community organization. The locations are a veritable "melting pot", since the residents comprise of people from various backgrounds and regions of the country including foreigners. All these persons migrated to the towns with the aim of engaging themselves in some sort of profitable economic activity.

\section{Underlying drivers of recurrent flooding}

Explaining the situation of rising tides of urban flood waters is not as easy as its occurrence. Researchers into city floods in Cameroon just as their counterparts the world over are divided on the role of the cardinal forcings as climate variability and landscape modifications within the city. An X-ray of these two sets of factors is made in this subsection in order to establish the root cause(s) of this malignant urban problem in Cameroon.

\section{Climate variability}

A significant proportion of researchers into urban problems view climate variability as the catalyst to the widening and deepening scope of the recurrent inner city floods today. This linkage in the case of Cameroonian cities is not very obvious especially when inter-annual trends in rainfall totals are considered. The established trends of inter-annual rainfall totals (Figure 5) and totals for the flood endemic months (June, July, August, September and October) have shown an overall drop over the years for the cities of Douala and Limbe. Only the city of Kumba has recorded increasing trends. Drawing conclusions from this established climatic trend has induced erroneous dismissal of the climate variability thesis in explaining urban floods in Cameroon [5].
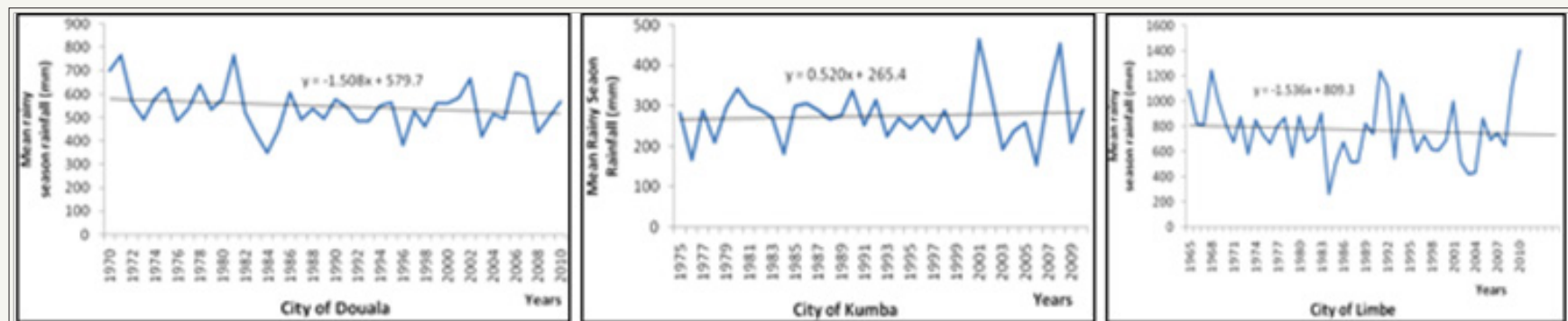

Figure 5: Temporal variations in rainy season rainfall totals. 
A closer look however reveals that this trend disguises the severe erractic pattern of secular temporal variations of rainfall totals. For instance, the graphs (Figure 5) reveals pronounced fluctuations in the annual rainfall totals. From several years, records have registered sudden upsurge in rainfall totals. In recent times this has been 2001, 2002, 2005, 2007, 2012, 2015 and 2016 for Douala; 2001, 2007, 2008, 2010, 2012, 2014 and 2016 for Kumba; and 2001, 2005, 2009, 2010, 2012, 2013, 2015 and 2016 for Limbe. This explains why severe flooding scenarios in these cities is not yearly but has a return period of two to three years which is even thinning down to one year. These years have coincided with some of the severe flooding scenarios on record in these cities. Another pointer of climatic variability is the fact that the rainfall total received in the month of August has been on a steady increase in all the cities.

A further dimension of climate variability is the increasing trends in mean annual rainfall intensities for the rainy season months for the cities and their whole drainage basins as shown on (Figure 6). The rainy season mean rainfall intensity has risen over the years in the cities. The result therefore is the recurrent flooding recorded in many parts of these cities during the peak rainy season months. The analysis of the rainfall variations establishes that floods occurrence within these coastal cities in Cameroon is explained more by increasing mean rainfall intensities than to mere changes in annual rainfall totals.
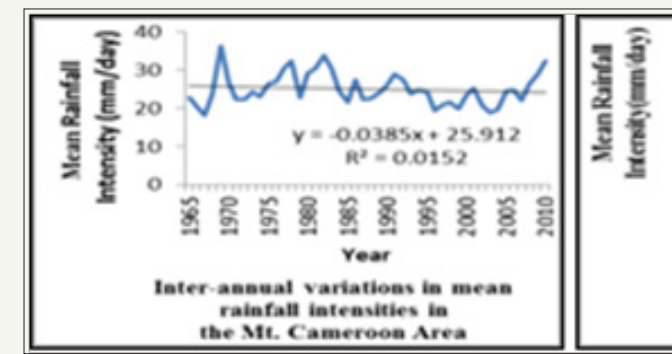

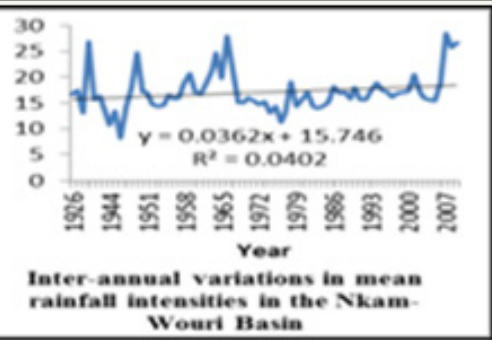

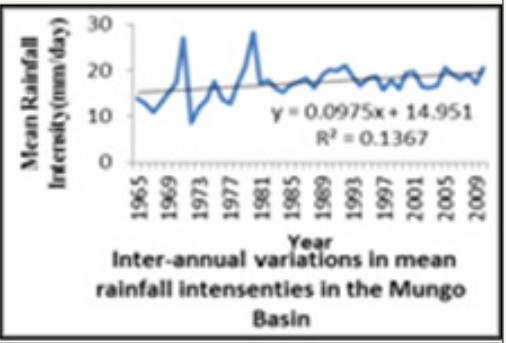

Basin

Figure 6: Temporal variations of mean annual rainfall intensities.

The higher intensity rainfall induces more surface runoff that provokes sudden soaring of discharge far beyond the carrying and transfer capacity of natural stream channels and the urban drain systems. Through these, it can be concluded that climate variability contributes significantly to the natural and phenomenal floods that have been plaguing these coastal urban centres within Cameroon. This conclusion is contrary to that established by [4,5] and earlier that the climatic factor cannot explain the magnitude of urban floods in Cameroon.

Rather, it is in line with the view that most cities are at increasing risk from the effects of climate change, including increasing heat waves and, for coastal cities, rising sea levels and storm surges [6]. Despite this established linkage between hydroclimatic variability and inner city rainy season flooding, there is still need to analyse the anthropogenic factors operating within these urban landscapes.

\section{The pirate urbanisation process}

A conspicuous trait of Cameroonian urbanisation just as that of other Third World Countries is its pirate nature. The three cities have sprawled spontaneously and their burgeoning population has not been matched by growth of necessary social support amenities as adequate proper housing, transport networks and waste disposal facilities and proper planning. The sprawling effects of these snowballing "these giant city ecosystems" have been dramatic land cover and land use changes. This landscape transformation in favour of urban fabric has modified very significantly the hydrological characteristics of these cities.

There has been extensive deforestation (degradation and complete clearance) especially the mangrove plant communities and wetlands that hitherto served as the "kidney of the land" in the cities and surrounding areas. The transformed surfaces are now more exposed to storm battering hence increasing the volumes of overland flow generated. This deforestation thesis is supported by the fact that the rainforest absorbs about 35\% of rainfall. The proportion drops below $20 \%$ after logging and even further to about $12 \%$. Furthermore, the extensive pavements and tarred surfaces have reduced the degree of permeability and porosity of the surfaces, thereby lowering the infiltration capacities and rates within the cities. This has contributed in exacerbating the flooding phenomenon in these urban centres. This is because the heightened storm discharge gushing into the urban streams, wetlands and urban drain networks is laden with much eroded and transported sediments and objects swept along its path.

These sediments and objects accumulate and progressively lower the cross sectional area of the channel. This causes morphological changes in the alignment of the river channel, thereby reducing its capacity to hold and transfer water especially during the peak rainy season months. These land cover and land use mutation have induced modifications in the hydro-geomorphic characteristics of the cities. The drainage basin morphometric property of Average Bifurcation Ratio (ABF) has dropped significantly within the cities. For instance, in the city of Kumba the (ABF) has dropped by as much as $25 \%$ [7].

This indicates a rising flood risk within the cities. The influence of the modification of the urban hydro-geomorphology is reinforced by the unfortunate offshoots of the rapid and haphazard ongoing urbanisation within these urban centres. The many consequent urban misnomers have rendered these cities more susceptible to 
flooding. A commandeering phenomenon is imposing colonisation of hitherto flood plains and wetlands by shanty towns, and also excessive dumping of all categories of waste into the narrow drains and vegetation choked rivers as shown on (Figure 7). The plastic bottle crisis needs some focus.
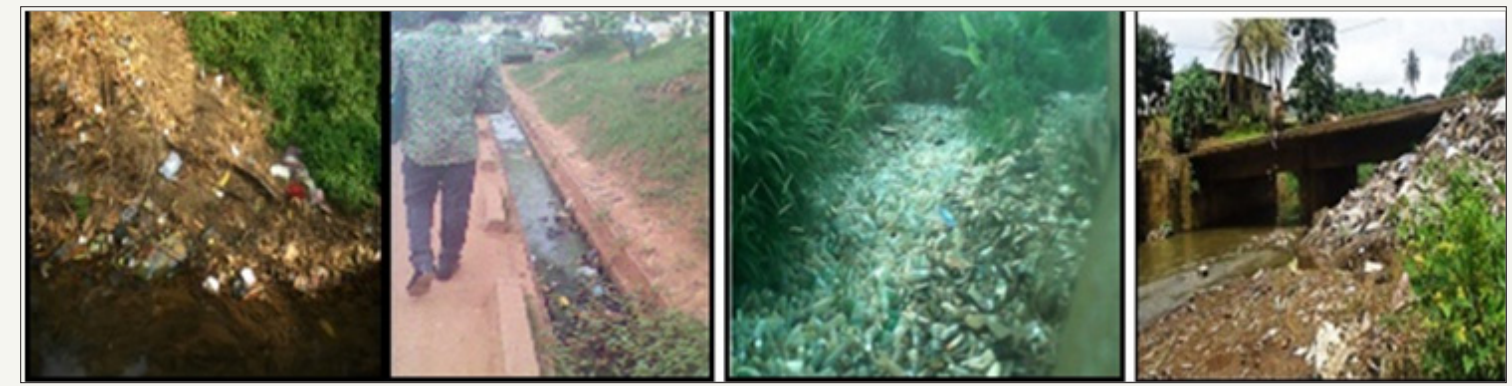

Figure 7: Urban drainage systems choked by waste to highly reduced water carriage potentials

The rapid expansion in the use of disposable plastic bottles which are relatively cheap has made them constitute a significant portion of urban garbage. During rainstorms, overland flow sweeps them in great quantities since they are light and float easily. They end up in drains and stream channels where they pile up at bridging points forming check dams that block the now elevated channel storm discharge. Wherever this occurs, during intense rainfall events, the surface run off frequently exceeds the carrying capacity of the town sewer system. Consequently, there is overspill of the channel runoff to surrounding humanised river plains, thereby yielding flooding of the urban environment.

It is observed that the haphazard urban growth and the nonrespect of urban plan regulations appear to have surpassed the municipal authorities. Their actions always come late when the urban misnomers have been established. These aspects of poor urban planning and management have reduced the capacity of the sewage system and stream segments located in the inner city to drain off efficiently excess storm runoff flowing over the city landscape. This unfortunately is at the moment in time when the mean rainfall intensity and rainfall totals for the peak rainy season months are all on the rise.

Consequently, the capacity of many existing drains is now too small to contain the increased volume of overland flow in these urban milieus and easily become over flooded during high intensity storms. This is therefore in line with conclusions from earlier studies that "as cities expand, the increased constructions further limit their natural drainage capacity and each time it rains heavily, flood risks have increased" [6], and that "poor waste management, silting of water courses, deforestation of slopes, bastardisation of flood plains and wetlands by illegal settlements stand out as drivers of city flooding in Cameroon" [3,8].

The recurrent inner city floods within the coastal lowland cities of Douala, Kumba and Limbe in Cameroon is therefore a product of both the changing hydroclimatic setting and the inadequate capacity of the urban drainage systems, both opened and closed conduits, to evacuate excess storm runoff that has collected locally from the immediate urban area. As a concluding note to this analysis, it is certain that without the enormous land cover and land use mutations that have installed widespread urban misnomers, storm discharge will normally drain off through the natural pathways (stream channels) and the excess storm discharge buffered by the natural kidneys of the land (wetlands). That flooding should occur is the work of nature (capricious climate) but that the flood events today have extremely high peaks and recurrence rate lies in the hand of man (poor urban planning).

This therefore lends to the conclusion that man sets the stage for nature to operate as far as inner city flooding is on the Coastal Lowlands of Cameroon. This is contrary to earlier postulations which saw in inner city flooding in Cameroon only the hand of man and downplaying the work of nature. This manifestation of urban flooding scenarios in Cameroon lends credence to the conclusion that "the hydrological cycle plays a fundamental role in our natural environment. Man attempts always to modify it for his own needs. This often leads to undesirable results" [9], in this case flooding.

\section{Conclusion and Recommendation}

The main impacts of the study of this evaluative paper lie in the following:

a. The vulnerability analysis reveals that these coastal cities in Cameroon are naturally predisposed to flooding. There is however an inter-city and intra-city variation in the degree of vulnerability. When all the natural flood indicators are put together, the city of Limbe stands out as the most vulnerable to flooding, followed by Kumba, while Douala is theleastvulnerable. Any distortion of this order transcends the operation of natural forces into the realm of anthropic modifications. Within the cities, first degree flood vulnerability zones, low-lying sites along river valleys, and poorly drained flood plains and coastal marshes sites [10]. These very high flood probability zones are more numerous in the areas suffering second (moderate) and third (low) degree flood vulnerability.

b. There is a paradigm shift in the explanation of recurrent urban floods. It is established here that the work of nature (hydroclimatic and geormorphic mutations) is the primary cause of inner-city flooding and standout as the most highly significant driver of the recurrent city floods. Man's role through haphazard and pirate urbanisation process is more secondary. 
c. Rain water induced overland flow remains the main source of floods water in all the cities. Furthermore, the rising magnitude of impacts of the rainy season floods is linked to the loss of important land cover types as wetlands that served hitherto as kidneys to the land. Illegal colonisation of river valleys has contributed also to the problem.

d. Poor waste management is established as one arm of man that exacerbates the inner city flooding scenarios. The dimension of the problem has been magnified by the fragrant non-respect of existing town planning Laws and non-existence of urban master plan in some of these cities [11]. It is recommended that legislation should protect and regulate these measures. For instance, Law No. 2004/003 of 21/04/2004 in Section 1(1) state unequivocally that "except otherwise specially prescribed, any land in danger of a natural hazard (flood, erosion, landslide and earthquake), portions of state land classified as such an ecologically protected areas as defined by legislation, relating to environmental management, shall not be built on". Section 12 of the same Law states that "owners of hemmed in parcels or parcels without rainwater drainage ways, particularly plots located downstream, shall be entitled to seek and obtain a passage through neighbouring plots".

If this law whose cardinal goal is sustainable urban development was respected scrupulously by all, then urban watershed areas and the wetlands that normally soak excess overland flow generated within the towns would be avoided and floods will be no hazard to the urban dwellers [12]. This is because flood prone areas would be left uninhabited. All these lend credence to this assertive conclusion that in the case of urban floods in the coastal cities of Douala, Kumba and Limbe in Cameroon, "man sets the stage for nature to operate and that prevention is better than cure".

There is therefore need for urban authorities in these cities to bank on this new information generated on the flood vulnerability index and its primary drivers to provoke a re-assessment of the current highly curative (primary strategies) to more preventive (secondary and tertiary) measures and reflect on new supporting policy options [13-16]. These should be those that integrate rain water, waste and residual wetlands into all their urban landscape management in Cameroon especially those of Douala, Kumba and Limbe.

\section{References}

1. Law Ward (1997) A: old prophets of new city regions, Town and Country Planning to Regulate Town Planning in Cameroon.

2. Nkafu AJ (2011) Floods in Limbe. Unpublished Postgraduate Dissertation, ENS Yaounde, University of Yaounde I, Cameroon.

3. Lambi CM, Fogwe ZN (2001) The February 2000 floods in Down Yaounde. In: Lambi, Eze (Eds.), pp: 119-127.

4. Fogwe NZ (2008) The Cameroonian city counter flood response strategies of the $21^{\text {st }}$ Century. In: JASS, University of Buea, Cameroon 7(10): pp: 124-141.

5. Fogwe NZ, Lambi CM (2001) Combating Inundation in some Cameroonian cities: An Appraisal of Indigenous Strategies. In: Lambi (Ed.), pp: 133-146.

6. Global Water Partnership (2012) Management of Urban Floods in Dhaka City. News line, South Asia.

7. Nkemasong N (2006) Hydro climatic Variations and Impacts on the Population of Adjoining Northern Slopes of Mount Cameroon. University of Buea, Cameroon.

8. Fogwe NZ, Asue EN (2016) Cameroonian Urban Floodwater Retaliations on Human Activity and Infrastructural Developments in Channel Flood Ways of Kumba. Current Urban Studies 4(1): 85-96.

9. Knapp BJ (1979) Elements of Geographical Hydrology. In: George Alien, Unwin (Eds.), London.

10. Balgah SN (2013) Land Tenure and Land Use Dynamics in Limbe City, South West Region of Cameroon. TI Journal of Agriculture Science Developments 2(3): 14-24.

11. Dasmann RF (1973) Ecological Principles for Economic Development. John Wiley \& Sons Ltd, New York, USA.

12. Lambi CM (2001) Environmental Issues: Problems and Prospects. In: Bamenda (Ed.), Unique Printers, India.

13. Lambi CM, Eze BE (2001) Readings in Geography. In: Bamenda (Ed.), Unique Printers, India.

14. (2014) Climate Variability and implications on Hydrological Systems within the Southern Volcanic Province of Cameroon. University of Buea, Cameroon.

15. Republic of Cameroon (1974-2005) Land Tenure and State lands. In: Regime Foncier, domanial (Eds.), Les Editions de l' Imprimerie Nationale.

16.Zoleta Nantes DB (2000) Flood Hazard Vulnerabilities and Coping Strategies of Residents of Urban Poor Settlements in Metro Manila, the Phillippines. In: parker DJ (Ed.), London, p: 69-88.

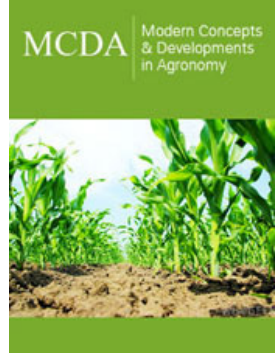

Modern Concepts \& Developments in Agronomy

\section{Benefits of Publishing with us}

- High-level peer review and editorial services

- Freely accessible online immediately upon publication

- Authors retain the copyright to their work

- Licensing it under a Creative Commons license

- Visibility through different online platforms 